\title{
Professional Indemnity Insurance for Dental Practitioners in India
}

${ }^{1}$ Kedarnath N Seshappa, ${ }^{2}$ Shruthi Rangaswamy, ${ }^{3}$ Arun K Puttegowda

\begin{abstract}
Dental practitioners are at high risk of facing medical negligence cases because of the nature of the work and high costs involved in the treatment. Professional indemnity insurance protects the doctors from the medical negligence claims and legal liabilities and thus provides financial security. The purpose of this paper is to highlight the importance of professional indemnity insurance and to understand various terminologies in choosing the right policy.
\end{abstract}

Keyword: Dentist, Indemnity policy, Professional liability.

How to cite this article: Seshappa KN, Shruthi R, Puttegowda AK. Professional Indemnity Insurance for Dental Practitioners in India. J Health Sci Res 2018;9(2):38-40.

Source of support: Nil

Conflict of interest: None

\section{INTRODUCTION}

The Indian society has observed a lot of changes after 1986 with the introduction of consumer protection act, especially in the medical profession. Earlier a Doctor treating a patient was seen as a noble service and is now reduced to consumer and service provider.

The essence of the doctor-patient relationship is disappearing resulting in lawsuits against the doctors, and there has been a steady increase in the number of such cases/suits in the recent years. ${ }^{1}$ The entry of corporate companies into healthcare has also influenced the dynamics of this change. Dental practitioners because of the nature of the work and the high costs involved in such treatments are at high risk of facing a medical negligence case suit.

A single case of medical negligence can cost heavily to the dentist, professionally and financially as well. Reputation is an integral part of the medical profession and maintaining the same is very critical. The need of the hour, in the present litigious world, is to secure professional practice by way of professional indemnity insurance.

\footnotetext{
${ }^{1,2}$ Professor, ${ }^{3}$ Reader

${ }^{1-3}$ Department of Oral and Maxillofacial Surgery, RajaRajeswari Dental College and Hospital, Bengaluru, Karnataka, India

Corresponding Author: Kedarnath N Seshappa, Professor, Department of Oral and Maxillofacial Surgery, RajaRajeswari Dental College and Hospital, Bengaluru, Karnataka, India, e-mail: kedarnathns@gmail.com
}

\section{INDEMNITY}

The word indemnity means security or protection against a loss or other financial burden. ${ }^{2}$ A person who offers service based on an expert knowledge is a professional, and an indemnity policy or insurance that is made to suit a particular profession is called professional indemnity insurance.

In case of proven medical negligence, the insurance company will pay for the compensation awarded to the Dentist and also gives a sense of mental security. Hence it is prudent for every dentist to have the professional indemnity insurance cover.

A professional indemnity policy protects the doctors against:

- Injury or death caused by negligence and claims made against such errors.

- The liability which may include defending advocate charges, costs of investigation, representation.

\section{How to Choose an Insurance Policy for Professional Indemnity}

Insurance policy varies across insurance companies and insurer. The professional choosing such insurance cover has to go through the document in detail. Professional/ the doctor-insurer should be thorough with many terminologies mentioned in the policy and consider various factors that best suits his/her practice before finalizing one such policy.

Some of the terminologies to be understood are listed in Table 1 .

\section{Professional Services}

Professional services provided will be clearly described in the document, and the professional has to ensure that the policy adequately covers the requirements.

Table 1: Terminologies

\begin{tabular}{ll}
\hline Professional services & Limit of claim \\
\hline $\begin{array}{l}\text { Anyone accident and anyone } \\
\text { year limit }\end{array}$ & Claims made policy \\
Occurrence policy & Extended reporting period \\
Anyone claim policy & Aggregate policy \\
Runoff cover & \\
\hline
\end{tabular}




\section{Limit of Indemnity}

Limit of indemnity means the sum insured in the policy that can be claimed. This should be based on the losses that might arise in inadvertent circumstances. Most of the indemnity insurance cover starts around one lakh, and the limit of indemnity can be tailored to the needs of the individual or the group or institution.

While choosing the limit of indemnity, one should consider the following factors:

- The nature of the profession like diagnostic, surgical, cosmetic procedures.

- The size and extent of the service provided in a small clinic or big hospital.

- The extent of the risks involved in surgical procedures, general, and sedation.

- Type of patients seeking the service: Children, medically compromised patients, and elderly patients.

- The place where services are offered: Rural, semi-urban, urban, major city, metro city and

- Claims made against those in the same profession.

The sum insured is fixed per accident and per policy period also called anyone accident (AOA) limit and any one year (AOY) limit respectively. ${ }^{3,4}$

\section{Duration of Coverage}

One should explore the policy for details on the period of insurance cover related to renewal and non-renewal of policy, as there can be variation in file suits of negligence on a doctor from nil to many at a point of time.

There can be different types of indemnity cover like:

- Claims made coverage

- Occurrence coverage

The differences between occurrence coverage and claims made coverage are ${ }^{5,6}$ (Table 2):

Table 2: Difference between occurrence coverage and claims made coverage

\begin{tabular}{ll}
\hline Occurrence coverage & Claims made coverage \\
\hline $\begin{array}{l}\text { Protects against } \\
\text { incidents which occurred } \\
\text { during policy period, } \\
\text { does not consider the } \\
\text { time of claim }\end{array}$ & $\begin{array}{l}\text { Policy covers any claims defined } \\
\text { when both the incident and the } \\
\text { claim occurred during the active } \\
\text { policy period. }\end{array}$ \\
coverage & $\begin{array}{l}\text { Provides coverage from the time } \\
\text { of first policy and continued active } \\
\text { policies by renewals. } \\
\text { Once premiums stop the } \\
\text { coverage stops } \\
\text { An insurance company will not } \\
\text { provide the claims made after the } \\
\text { policy periods, even if the incident } \\
\text { happens during the policy period. } \\
\text { respond to claims even } \\
\text { after termination of the } \\
\text { policy. }\end{array}$ \\
$\begin{array}{l}\text { No need for extended } \\
\text { coverage. }\end{array}$ & $\begin{array}{l}\text { The policy will cover claims even } \\
\text { afteriod only when the insured had } \\
\text { purchased the "tail" coverage or } \\
\text { extended period insurance. }\end{array}$ \\
\hline
\end{tabular}

\section{Basis of Cover}

The process of indemnity cover varies from company to company depending on the treatment services provided at the place. There can be a variation to the sum insured in policy depending on whether the policy is anyone claim or aggregate policy.

In 'anyone claim' policy, coverage for each individual claim during active policy period can be up to the full limit of the insurance made, but in an 'aggregate' policy, coverage includes a full limit for all the claims that were raised in the active period of the policy.

For example, if two ₹ 75,000/- claims are made against $₹ 1,00,000 /-$, in 'anyone claim' policy the company would cover the expenses of both claims since both are below the ₹ $1,00,000 /-$ limit.

If two ₹ 75,000/- claims are made against rupees $1,00,000 /-$ in an 'aggregate policy', the company will cover expenses only up to the ₹ 1,00,000/- limit. As the claims total ₹ $1,50,000 /-$, the remaining money the company will not cover ₹ $50,000 /$ - which is excess of ₹ 1,00,000/- limit.

In general, 'anyone claim' is considered to be more comprehensive policy and the process of insurance coverage can vary from company to company depending on the services provided. ${ }^{7-9}$

\section{Extended Reporting Period or Runoff Cover}

Period of limitation in the law allows the grieved patients to file a case up to 3 years after the treatment. In this regard, the extended reporting period becomes important if the doctor plans to close the clinic or hospital. Even though the doctor has stopped providing the services, he is still liable for the services provided up to 3 years after the closure of the clinic or hospital.

The costs may be high in purchasing an extended policy or tail coverage, but it is still beneficial compared to the risks involved. ${ }^{10,11}$

\section{Exclusions of Professional Indemnity}

One has to carefully look for the exclusions mentioned in the policy before buying the policy. Acts committed under influence of alcohol/drugs, any criminal acts, personal damages, loss of goodwill, any penalties, and also any medical treatments given for, weight reduction, cosmetic/plastic surgery procedures, and any condition associated with human immune virus (HIV)/acquired immune deficiency syndrome (AIDS) and non compliance with statutory provisions are not covered by the insurance policy. ${ }^{12}$ 


\section{HOW TO CLAIM}

In any case of untoward incidents, the information has to be rendered to the insurance company as soon as possible, and the insured should communicate all the legal proceedings if any, to the insurance company, so that the company can arrange for the defense of the case. The insurance companies cover only the civil liabilities and not the criminal liabilities. ${ }^{4}$

\section{RENEWAL OF POLICY}

Continued coverage by the professional indemnity insurance throughout the practicing years and up to 3 years after closure of the professional practice is required to make sure one is protected.

In case of non-renewal, not only the indemnity insurance ceases to exit from the present cases, but also from the previous years when the policy was active, and the insurance company will not provide protection for any claim filed in case of non-renewal.

At times, if the claim rates are more, the insurance company reserves the right to renew the policy. In such a case one can approach another insurance company for continued coverage.

\section{CONCLUSION}

The healthcare profession is facing the new challenges that continue to grow unopposed. With the increased awareness nowadays, the general public is looking for accountability from the healthcare service providers for the adverse consequences they experience resulting in increased lawsuits.

With the increase in affordability, the expectations of the people regarding the standards of professional care and service are also high and coupled with these are the new, revised laws protecting the consumers, all leading to a surge of potential claimants. As this trend continues, there is more need for services of the medicolegal advisor, who can guide and protect the professional against the frivolous claims.
The need for professional indemnity cover is more relevant than ever in today's litigious world.

\section{REFERENCES}

1. Secureno-Blogger. How professional indemnity insurance can protect the doctors against legal liability? SecurenowBlog Nov 2016. https://securenow.in/blog/how-professionalindemnity-insurance-can-protect-doctors-against-legalliability.

2. English oxford living dictionaries. Definition of indemnity in English. Jun 2017. Available from: https:// en.oxforddictionaries.com/definition/indemnity.

3. Beniwal H. Professional indemnity insurance for doctors in India. The financial literates blog. Jul 2016. http://www. tflguide.com/2016/07/professional-indemnity-insurancedoctors-india.html.

4. Professional indemnity policy. Jul 2017. Available from: http://newindia.co.in/Content.aspx?pageid $=49$.

5. Ramakrishna V Professional indemnity insurance better being safe than sorry. newsetter Apr 12 pg; 01-02 India insure. http://www.indiainsure.com/pdf/Inotes-Apr12.pdf.

6. Claims Made vs. Occurrence Form Professional Liability Policies. Aug2017. Availablefrom:http://www.americanprofessional.com/ wp-content/uploads/Claims-Made-vs-Occurrence_AC.pdf.

7. Professional indemnity aggregate or any one claim basis. May 2017 Available from: https://www.johnheath.com/news/ professional-indemnity-aggregate-or-any-one-claim-basis/\#. WUC5jJKGPMw.

8. Professional Indemnity Insurance - 'Aggregate' or 'Any One Claim'? May 2017. Available from: https://www.coulsonpritchardonline.co.uk/articles/professional-indemnityinsurance-aggregate-or-any-one-claim.php.

9. Adam Bishopon, Insurance indemnity limits, types and usage examples. January 20, 2011. Available from: http:// riskheads.org/insurance-indemnity-limits-types-examples.

10. Understanding Extended Reporting Periods or "Tail" Coverage. Apr 2017. Available from: http://www.theaiatrust.com/filecabinet/extended-reporting-options_ownership-transition.pdf.

11. FAQs on Extended Reporting ("Tail") Coverage, standing committee on lawyer's professional liability. May 2017. Available from: https://www.americanbar.org/groups/ lawyers_professional_liability/resources/extended_reporting_coverage.html.

12. Professional indemnity policy for doctors and medical practitioners. Apr 2017. Available from: https://securenow.in/ commercial-liability-insurance/doctor-professionalindemnity. 